\title{
Microbial colonisation and litter decomposition in a Cerrado stream are limited by low dissolved nutrient concentrations
}

\author{
Adriana O. Medeiros ${ }^{1, *}$, Marcos Callisto ${ }^{2}$, Manuel A.S. Graça ${ }^{3}$, Verónica Ferreira ${ }^{3}$, Carlos A. \\ Rosa $^{4}$, Juliana França ${ }^{2}$, Ana Eller ${ }^{2}$, Renan S. Rezende ${ }^{5}$ and José Francisco Gonçalves Jr. ${ }^{5}$ \\ ${ }^{1}$ Departamento de Botânica, Instituto de Biologia, Campus Universitário de Ondina, Universidade Federal da \\ Bahia, 40170-115, Salvador, BA, Brazil. \\ ${ }^{2}$ Departamento de Biologia Geral, Instituto de Ciências Biológicas, C. P. 486, Universidade Federal de Minas \\ Gerais, Belo Horizonte, MG, 31270-901, Brazil. \\ ${ }^{3}$ MARE - Marine and Environmental Sciences Centre, Department of Life Sciences, Faculty of Sciences and \\ Technology, University of Coimbra, 3004-517 Coimbra, Portugal. \\ ${ }^{4}$ Departamento de Microbiologia, Instituto de Ciências Biológicas, C. P. 486, Universidade Federal de Minas \\ Gerais, Belo Horizonte, MG, 31270-901, Brazil. \\ ${ }^{5}$ Departamento de Ecologia, Instituto de Ciências Biológicas, Universidade de Brasília, DF, 70190-900, Brazil. \\ *Corresponding author: guikapt@yahoo.com.br, adrianamedeiros@ufba.br
}

Received: 03/07/2014 Accepted: 16/01/2015

\begin{abstract}
Microbial colonisation and litter decomposition in a Cerrado stream are limited by low dissolved nutrient concentrations

Litter decomposition in the streams of the Brazilian Cerrado (Savannah) is generally slow. In this study, we tested the hypothesis that leaf litter decomposition is limited by low dissolved nutrient availability. We measured the decomposition of the litter of the riparian species Protium heptaphyllum in a local stream under nutrient enrichment promoted by nutrientdiffusing substrates (nutrient-enriched treatment; $\mathrm{N}$ and $\mathrm{P}$ ), and under control conditions (no added nutrients). Leaves were enclosed in fine $(0.5 \mathrm{~mm})$ mesh bags and immersed in the stream. Replicate samples were retrieved periodically over 56 days. At the end of the experiment, leaf mass loss, associated microbial biomass (ATP and ergosterol) and fungal sporulation rates were significantly higher in nutrient-enriched bags than in control bags. These results suggest that litter decomposition in certain Cerrado streams is partially limited by the low availability of dissolved nutrients.
\end{abstract}

Key words: Microbial decomposers, headwaters, litter processing, nutrient enrichment, savannah streams.

\section{RESUMEN}

La colonización microbiana y la descomposición de hojarasca en un arroyo del Cerrado está limitada por la baja concentración de nutrientes disueltos

La descomposición de hojarasca en los arroyos del Cerrado Brasileño (sabana) es generalmente lenta. En este estudio, testeamos la hipótesis de que la descomposición de la hojarasca se ve limitada por la baja disponibilidad de nutrientes disueltos. Medimos la descomposición de la hojarasca de una especie riparia, Protium heptaphyllum en un arroyo local bajo dos condiciones: la primera con suministro de nutrientes utilizando sustratos difusores de nutrientes (tratamiento "nutriente", $N \& P$ ), la segunda condición (control) donde no fueron adicionados nutrientes. Bolsas de malla fina (0.5 mm) con hojas fueron introducidas en el arroyo y se retiraron del río periódicamente réplicas durante 56 días. Al final del experimento, las tasas de descomposición, la biomasa microbiana (ATP y ergosterol) asociada a las hojas y las tasas de esporulación fueron significativamente más altos en las hojas expuestas al enriquecimiento con nutrientes que en la hojas control. Estos resultados sugieren que la descomposición de la hojarasca en algunos arroyos del Cerrado está parcialmente limitada por la baja disponibilidad de nutrientes disueltos.

Palabras clave: Descomponedores microbianos, ríos de cabecera, procesamiento de hojarasca, enriquecimiento de nutrientes, arroyos de sabana. 


\section{INTRODUCTION}

The decomposition of allochthonous organic matter is an important ecosystem process in loworder forest streams. In these streams, the riparian canopy limits light reaching the streambed, and such light limitation reduces stream primary production. Additionally, riparian vegetation supplies streams with leaf litter (Webster \& Benfield, 1986; Abelho, 2001). After it enters the water, leaf litter is decomposed by an array of organisms that includes microbes (primarily bacteria and aquatic hyphomycetes) and invertebrate detritivores (Hieber \& Gessner, 2002; Pascoal \& Cássio, 2004). Aquatic microbes colonise the litter soon after it enters the streams, macerate it through the action of extracellular enzymes, mineralise organic carbon and convert it into biomass (Baldy et al., 2007). These activities lead to the production of fine particulate and dissolved organic matter, $\mathrm{CO}_{2}$, and reproductive propagules, resulting in litter mass loss (Gessner \& Chauvet, 1994). Microbial degradation and biomass accumulation on leaf litter increase its nutritional quality and make litter more attractive to detritivores, leading to further litter mass loss (Graça, 2001).

Microbial communities and the rates at which litter decomposes can be affected by changes in environmental conditions, with consequences for foodwebs and ecosystem functioning (Gessner \& Chauvet, 2002; Lecerf \& Chauvet, 2008). Nutrient enrichment of freshwaters is a global problem driven by increases in the use of fertilisers and in atmospheric nitrogen deposition (Rockström et al., 2009; Vörösmarty et al., 2010). Such enrichment often stimulates microbial activity and litter decomposition (Gessner \& Chauvet, 2002; Young et al., 2008; Ferreira et al., 2015). However, most studies addressing the effect of nutrient enrichment on litter decomposition have been performed in temperate streams (Ferreira et al., 2015; but see Rosemond et al., 2002; Ardón et al., 2006; Stallcup et al., 2006; Abelho et al., 2010), and generalisations to tropical streams can be questionable given the substantial differences between temperate and tropical stream systems.

Many pristine temperate streams generally have a lower water temperature, a higher density of detritivores, and a higher aquatic hyphomycete species richness than tropical streams (Gonçalves et al., 2006; Boyero et al.,2011; Ferreira et al., 2012; Jabiol et al., 2013; Bruder et al., 2014). Additionally, research conducted in temperate systems has shown positive relationships between nutrient concentration and litter decomposition (Gulis et al., 2006), between species richness of aquatic hyphomycetes and litter decomposition (Bärlocher \& Corkum, 2003), and between temperature and nutrient concentration and litter decomposition (Ferreira \& Chauvet, 2011). Complementary research is lacking in tropical savannah (Cerrado) streams, where nutrients tend to be lower and temperature is generally higher (Gonçalves et al., 2007).

The South American savannah or Cerrado is the $2^{\text {nd }}$ largest biome in Brazil, one of the world's 25 "biodiversity hotspots", and the most diverse of the world's savannahs (Myers et al., 2000). Cerrado soils are old and highly weathered. For this reason, they are nutrient poor, and this deficiency of nutrients produces low concentrations of dissolved nutrients in headwater streams (Markewitz et al., 2006; Silva \& Vasconcelos, 2011). The presence of nutrient-poor soils can also result in leaves with a low nutrient concentration (Alvarez-Clare \& Mack, 2011; Ordoñez et al., 2009), with high concentrations of secondary compounds (e.g., tannins and polyphenolics), and with strong physical defences (e.g., greater toughness). These characteristics make leaves of plants growing on nutrient-poor soils more recalcitrant than leaves from plants in nutrient-rich soils (Coley \& Barone, 1996; Silva \& Vasconcelos, 2011). As a result of these constraints, which limit microbial colonisation and activity, leaf litter decomposition in Cerrado streams is often slow (Gonçalves et al., 2006; Moretti et al., 2007a, b) and potentially sensitive to human-induced nutrient enrichment.

Our study assessed the effect of nutrient enrichment on microbial colonisation and decomposition of leaf litter in an oligotrophic stream in the Brazilian Cerrado. We hypothesised that microbial activity and the rate at which litter decomposes are limited by low nutrient concentration in water and should be stimulated by nutrient enrichment. 


\section{MATERIALS AND METHODS}

\section{Study area}

This study was conducted in the Indaiá stream in Serra do Cipó National Park, Minas Gerais, Brazil (19 $16.4^{\prime} \mathrm{S}, 43^{\circ} 31.2^{\prime} \mathrm{W}, 1450 \mathrm{~m}$ a.s.l.). The climate in this region is Cwb Köppen-mesothermic; annual air temperature varies between 17 and $20^{\circ} \mathrm{C}$ and annual precipitation between 1450 and $1800 \mathrm{~mm}$ (Giulietti et al., 1997). The number of endemic plants is considered high (Giulietti et al., 1997). The streams in the Cipó area have a narrow (5-10 $\mathrm{m}$ wide), but very dense tree riparian zone, which casts deep shade on the streambeds. The streambeds are composed of bedrock, gravel, and coarse sand (Gonçalves et al., 2006).

During the experiment, the water temperature in the stream ranged from 14 to $21^{\circ} \mathrm{C}$. The waters were slightly acidic ( $\mathrm{pH} 5.0-6.6)$, well oxygenated $(7.5-8.5 \mathrm{mg} / \mathrm{L})$, and with low conductivity (maximum $10 \mu \mathrm{S} / \mathrm{cm}$ ) and low nutrient concentrations $(<100 \mu \mathrm{g} / \mathrm{L}$ of nitrate and $<17-68$ of $\mu \mathrm{g} / \mathrm{L}$ of orthophosphate). Physical and chemical characteristics of the stream water were measured over the study period $\left(23^{\text {rd }}\right.$ April to $28^{\text {th }}$ May 2008). Field meters were used to measure water temperature, $\mathrm{pH}$ (DIGIMED DM2P, São Paulo, BR), and electrical conductivity (DIGIMED DM-3P, São Paulo, BR); dissolved oxygen concentration was determined by the Winkler method (APHA, 2005; $n=3$ ). Dissolved nitrate concentrations were determined by the cadmium column reduction method and orthophosphate by the ascorbic acid method (APHA, 2005; $n=7$ ).

\section{Leaf litter incubation}

Leaves of Protium heptaphyllum (Aubl.) March. were selected for this study because this is a native species present in the riparian zone of many streams in the Cerrado, including the study stream. The leaves of $P$. heptaphyllum are tough and nutrient poor (Gonçalves et al., 2012), which should make its colonisation and decomposition by microbes sensitive to dissolved nutrient concentrations (Gulis \& Suberkropp, 2003a, b; Fer- reira et al., 2006). Abscised leaves were collected in litter traps in the riparian zone of the study stream, dried at room temperature, and stored in the dark until used. Portions of leaves weighing $2.9 \mathrm{~g}( \pm 0.2 \mathrm{~g}$, average $\pm \mathrm{SD})$ were sprayed with distilled water, placed in $20 \times 20 \mathrm{~cm}$ nylon bags $(0.5 \mathrm{~mm}$ mesh), and incubated in the stream on $23^{\text {rd }}$ April 2008.

Leaves were exposed to two nutrient levels: half of the litter bags were provided with $25-\mathrm{mL}$ nutrient diffusing substrates (NDS; hereafter referred to as 'enriched bags'), while litter bags without NDS served as controls (hereafter referred to as 'control bags'). NDS were prepared by dissolving commercial fertiliser briquettes (Nutriplast Industria e Comércio Ltda, Cascavel, Brazil) in $2 \%$ agar (5.6 g N/L NDS, $2.4 \mathrm{~g} \mathrm{P} / \mathrm{L}$ $\mathrm{NDS}$, and $2 \mathrm{~g} \mathrm{~K} / \mathrm{L}$ NDS). Twenty-five $\mathrm{mL}$ of agar solution were poured warm into $100 \mathrm{~mm}$ diameter Petri dishes and allowed to solidify in the refrigerator. The content of each Petri dish was wrapped in gauze to make a cylinder $\approx 10 \mathrm{~cm}$ in length. One NDS was fixed inside each enriched bag parallel to the opening. With this mode of placement, the NDS in each bag would be upstream from the leaf litter in the same bag when the bags were deployed in the stream. Bags with NDS were always placed downstream from control bags. NDS usually release nutrients slowly (Robinson \& Gessner, 2000; Abelho \& Graça, 2006); however, to ensure a relatively constant nutrient concentration in the enriched bags, the NDS were replaced weekly (Stallcup et al., 2006). The NDS approach to study the effects of nutrient enrichment on litter decomposition in streams has limitations because it does not allow any control of the rate of nutrient release over time (i.e., the nutrient release decreases over time) and space (i.e., it primarily affects the organisms inside and near the litter bags and not the surrounding environment) (Ferreira et al., 2015). However, in streams with the dimensions of the Indaiá ( $2.5 \mathrm{~m}$ width, $0.25 \mathrm{~m}$ depth), where vandalism is a risk, the use of NDS is an alternative to a more realistic and controlled whole-stream nutrient addition approach (Robinson \& Gessner, 2000; Abelho \& Graça, 2006; Stallcup et al., 2006; McKie et al., 2009; Abelho et al., 2010). 
Litter bags $(n=4)$ were retrieved after 7, 14, 21, 35, and 56 days, placed inside ziplock bags, and transported to the laboratory in ice chests. An extra set of litter bags $(n=5)$ was carried to the stream on day 0 and returned to the laboratory, oven dried $\left(60^{\circ} \mathrm{C}, 72 \mathrm{~h}\right)$, weighed, ignited $\left(550{ }^{\circ} \mathrm{C}, 4 \mathrm{~h}\right)$, and reweighed to allow determination of initial ash free dry mass (AFDM).

\section{Sample processing and determination of remaining leaf mass}

In the laboratory, the remaining leaf material was gently washed with distilled water, oven dried $\left(60^{\circ} \mathrm{C}, 72 \mathrm{~h}\right)$, weighed, ignited $\left(550^{\circ} \mathrm{C}, 4 \mathrm{~h}\right)$ and reweighed to determine the remaining AFDM. Five leaves were randomly selected from each litter bag, and four discs were cut from each leaf using a cork borer (12 $\mathrm{mm}$ diameter). The four sets of five discs were used for quantification of total microbial (ATP) and fungal (ergosterol) biomass, aquatic hyphomycete sporulation rate, and AFDM of leaf discs. Leaf discs for AFDM determination were oven dried, weighed, ignited and reweighed as for bulk material. The remaining AFDM, corrected for the discs removed, was expressed as a percentage of the initial AFDM.

\section{Total microbial biomass}

The microbial biomass associated with the decomposing litter was determined as ATP concentration according to Abelho (2005). Leaf discs were homogenised in $5 \mathrm{~mL}$ of $0.6 \mathrm{M}$ sulphuric acid (Sigma-Aldrich, Steinheim, Germany) containing $8 \mathrm{~g} / \mathrm{L}$ of oxalic acid (Sigma-Aldrich, Steinheim, Germany) and $5 \mathrm{~mL}$ of $0.05 \mathrm{M}$ HEPES (Sigma-Aldrich, St. Louis, MO, USA). The suspension was centrifuged $\left(20 \mathrm{~min}, 4^{\circ} \mathrm{C}\right.$, $10,000 \mathrm{~g})$ and the supernatant was filtered (0.2 $\mu \mathrm{m}$, PVDF, sterile, Millex-GV, Millipore, USA) and neutralised to $\mathrm{pH}$ 7.0. The light produced by the enzymatic reaction of ATP (FLAAN-1VL, Adenosine 5'-Triphosphate (ATP) assay mix, Sigma-Aldrich) was measured with a luminometer (Turner Designs TD-20/20, Sunnyvale, CA, USA). The results were expressed as nmoles ATP/g AFDM.

\section{Fungal biomass}

The fungal biomass associated with the decomposing leaf litter was determined as ergosterol concentration according to Gessner (2005). Leaf discs were stored in $10 \mathrm{~mL}$ of methanol/KOH (Sigma-Aldrich, Steinheim, Germany) at $-20{ }^{\circ} \mathrm{C}$ until extraction. Lipid extraction and saponification was performed at $80^{\circ} \mathrm{C}$ for $30 \mathrm{~min}$. The extract was then purified by solid-phase extraction (Sep-Pak Vac-RC-500 mg, Waters, USA) and quantified by high performance liquid chromatography (HPLC, Waters, model 625 LC System) by measuring absorbance at $282 \mathrm{~nm}$, at $35^{\circ} \mathrm{C}$. The results were expressed as $\mu \mathrm{g}$ ergosterol/g AFDM.

\section{Conidial production by aquatic hyphomycetes}

Conidial production by aquatic hyphomycetes associated with the decomposing leaf litter was determined according to Bärlocher (2005). Leaf discs were incubated in $250 \mathrm{~mL}$ Erlenmeyer flasks with $30 \mathrm{~mL}$ filtered stream water (Millipore filter GF/C, $0.45 \mu \mathrm{m}$, Billerica, MA, USA) on an orbital shaker (100 rpm) for $48 \mathrm{~h}$ at $18^{\circ} \mathrm{C}$. Aliquots of the conidial suspensions were filtered (Millipore, pore size $5 \mu \mathrm{m}$, Billerica, MA, USA), and the filters were stained with cotton blue $(0.05 \%$; Sigma-Aldrich, Steinheim, Germany) in $60 \%$ lactic acid (Vetec, Rio de Janeiro, Brazil). The filters were scanned under a compound microscope at $400 \times$ magnification (AxiostarPlus; Carl Zeiss, Oberkochen, Germany) to estimate the number of conidia retained. Sporulation rates were expressed as number of conidia $\mathrm{mg}^{-1}$ AFDM d $\mathrm{d}^{-1}$. The cumulative conidial production by the end of the incubation period (number of conidia/g of initial AFDM) was calculated by summing values of daily production at each sampling date and linearly interpolating values between each pair of consecutive dates.

\section{Statistical analyses}

Litter decomposition is usually expressed as decomposition rate per day $(k / d)$ because mass re- 

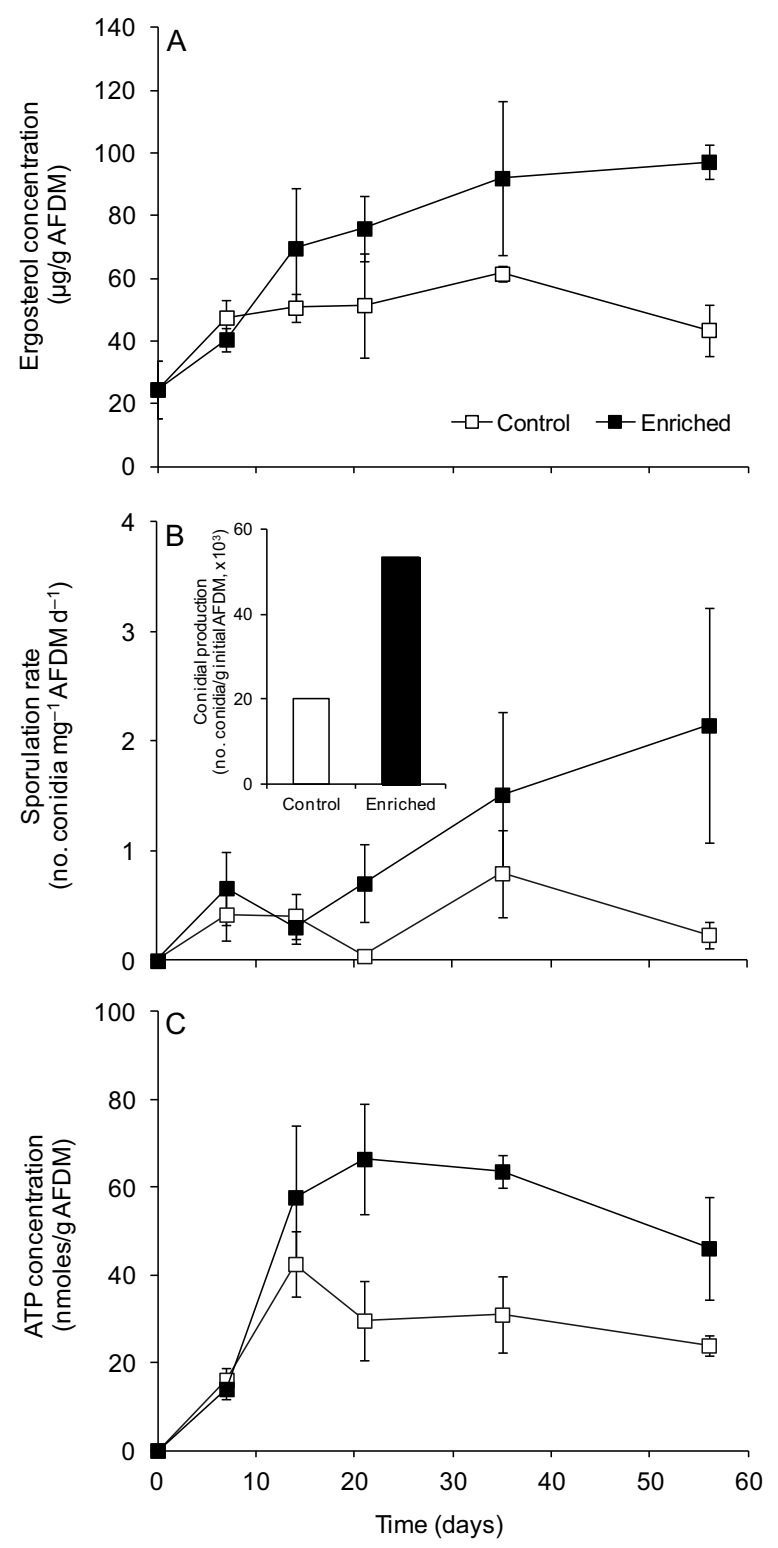

Figure 1. Ergosterol concentration (A), sporulation rate by aquatic hyphomycetes (B), cumulative conidial production by the last date (B, insert), and ATP concentration (C) associated with Protium heptaphyllum leaves incubated in the Indaiá stream, in control and nutrient-enriched litter bags for 56 days. Values are means \pm SE. Concentración de ergosterol (A), tasa de esporulación de los hifomicetos acuáticos $(B)$, producción acumulada de conidios hasta la última fecha (B, cuadro) y la concentración de ATP $(C)$ en las hojas de Protium heptaphyllum incubadas durante 56 días en el arroyo de Indaiá, bajo condiciones control y de enriquecimiento con nutrientes. Los valores son medias \pm ES.

maining over time usually fits a negative exponential or linear model (Webster \& Benfield, 1986).
However, our data did not fit either the negative exponential or linear model, even after the remaining mass was corrected for initial leaching. Therefore, litter decomposition was expressed as percentage mass (\% AFDM) remaining at the last sampling date, and the comparison between nutrient levels was made with a two-tailed t-test.

Ergosterol concentration (log $[x]$ transformed), sporulation rate by aquatic hyphomycetes $(\log [x+1]$ transformed), and ATP concentration ( $\log [x]$ transformed) were compared between treatments with two-way ANOVAs (nutrient level and time as categorical variables). Cumulative conidial production was compared between treatments with an ANCOVA (nutrient level as categorical variable and time as continuous variable). Normality was assessed with the Shapiro-Wilk test and homogeneity of variances with the Bartlett. Data were transformed when necessary to achieve a normal distribution or homoscedasticity. Analyses were performed with Statistica 7 software (StatSoft Inc., Tulsa, Oklahoma, USA).

\section{RESULTS}

After 56 days in the stream, the $P$. heptaphyllum leaf mass remaining was $94.5 \pm 1.5 \%$ AFDM (mean $\pm \mathrm{SE}$ ) in the control bags and decreased significantly to $87.4 \pm 0.6 \%$ AFDM in the nutrient-enriched bags (t-test, $p=0.011$ ).

The leaves were already colonised by fungi before being deployed in the stream ( $25 \mu \mathrm{g}$ ergosterol/g AFDM). Fungal biomass peaked after 35 days of leaf immersion in control bags $(62 \mu \mathrm{g}$ ergosterol/g AFDM), whereas it increased over the incubation period in the enriched leaf bags $(97 \mu \mathrm{g}$ ergosterol/g AFDM by day 56) (Fig. 1A). Fungal biomass was significantly higher in the nutrientenriched bags than in the control bags (two-way ANOVA (nutrient level), $F=10.23$, df $=1$, and $p=0.003$; Table 1).

Sporulation rates by aquatic hyphomycetes were generally very low (maximum of 2 conidia $\mathrm{mg}^{-1}$ AFDM d ${ }^{-1}$ in enriched bags by day 56) (Fig. 1B). The dynamics of sporulation rates were similar to those of fungal biomass and peaked 
by day 35 in the control bags while increasing over time in the nutrient-enriched bags (Fig. 1B). Again, fungal sporulation rates were significantly higher in the enriched than in the control bags (two-way ANOVA (nutrient level), $F=11.15$, $\mathrm{df}=1$, and $p=0.002$; Table 1). This difference resulted in 2.7-fold higher cumulative conidial production in the enriched than in the control bags by day 56 (ANCOVA, $F=11.31$, df $=1$, $p=0.012$; Fig. 1B).

Total microbial biomass in leaf litter peaked by day 14 in the control bags (42 nmoles ATP/g AFDM) and by day 21 in the nutrient-enriched bags (66 nmoles ATP/g AFDM; Fig. 1C). Total microbial biomass was significantly higher in the enriched than in the control bags (two-way ANOVA (nutrient level), $F=11.52$, df $=1$, and $p=0.002$; Table 1).

\section{DISCUSSION}

Increases in dissolved nutrient availability often stimulate microbial activity and litter decomposition in temperate streams (Gessner \& Chauvet, 2002; Young et al., 2008; Ferreira et al., 2015), and this was also the case for the current study. Protium heptaphyllum leaf mass loss was very low under ambient nutrient conditions (5.6\% after 56 days). This low level of loss can be partially explained by two factors: the low quality of the litter and the low concentrations of dissolved nutrients in the stream water (Gonçalves et al., 2007, 2012; Moretti et al., 2007b). Litter decomposition and associated microbial variables were stimulated by nutrient enrichment by $1.9-2.6 \times$, suggesting that microbial activity and litter decomposition were, to some extent, limited by the low availability of dissolved nutrients in the stream. Nutrient limitation in some Cerrado streams has been previously suggested by Moretti et al. (2007a), who reported that $P$. heptaphyllum leaf litter decomposed slower in Indaiá stream $(0.19 \mathrm{mg} \mathrm{N} / \mathrm{L}$ and $0.02 \mathrm{mg}$ P/L) than in a nearby stream with higher nutrient concentrations $(1.00 \mathrm{mg} \mathrm{N} / \mathrm{L}$ and 0.03 mg P/L). Nutrient limitation of litter decomposition has also been reported for many temperate (Gessner \& Chauvet, 2002; Young et al., 2008; Ferreira et al., 2015), and tropical streams in Costa Rica (Rosemond et al., 2002; Ardón et al., 2006; Stallcup et al., 2006). Although nutrients accelerated decomposition, values were still low when compared with those reported in other areas. Differences in the magnitude of the nutrient effects between studies may partially be attributed to the method used for nutrient enrichment (i.e., whole-stream nutrient addition vs. nutrient-diffusing substrates in our case) as suggested in a recent meta-analysis (Ferreira $e t$ $a l ., 2015)$. The use of NDS does not allow controlling the rate of nutrient release. Accordingly, nutrient concentrations do not became homogeneous in time and space. Thus, nutrient effects on litter decomposition are usually milder than when nutrient enrichment is performed at the

Table 1. Summary table for two-way ANOVAs performed on ergosterol concentration $(\log [x]$ transformed), sporulation rate by aquatic hyphomycetes $(\log [x+1]$ transformed), and ATP concentration (log $[x]$ transformed) associated with Protium heptaphyllum leaves incubated in the Indaiá stream, in control and nutrient-enriched litter bags for 56 days. Cuadro resumen de los ANOVAs de dos vías para la concentración de ergosterol log $[\mathrm{x}]$ transformado), de la tasa de esporulación de hifomicetos acuáticos $((\log$ [ $\mathrm{x}+1]$ transformado), y de la concentración de ATP (log [x] transformado), en las hojas de Protium heptaphyllum incubadas durante 56 días en el arroyo de Indaiá, bajo condiciones control y de enriquecimiento con nutrientes.

\begin{tabular}{|c|c|c|c|c|c|c|c|c|c|c|c|c|}
\hline \multirow{2}{*}{ Source of variation } & \multicolumn{4}{|c|}{ Ergosterol concentration } & \multicolumn{4}{|c|}{ Sporulation rate } & \multicolumn{4}{|c|}{ ATP concentration } \\
\hline & df & MS & $\mathrm{F}$ & $p$ & df & MS & $\mathrm{F}$ & $p$ & df & MS & $\mathrm{F}$ & $p$ \\
\hline Intercept & 1 & 124.00 & 5630.25 & 0 & 1 & 1.50 & 85.12 & $<0.001$ & 1 & 90.72 & 2355.99 & 0 \\
\hline Nutrient level & 1 & 0.23 & 10.23 & 0.003 & 1 & 0.20 & 11.15 & 0.002 & 1 & 0.44 & 11.52 & 0.002 \\
\hline Time & 4 & 0.05 & 2.37 & 0.075 & 4 & 0.06 & 3.59 & 0.017 & 4 & 0.34 & 8.72 & $<0.001$ \\
\hline Nutrient level $\times$ Time & 4 & 0.05 & 2.31 & 0.081 & 4 & 0.04 & 2.48 & 0.067 & 4 & 0.07 & 1.80 & 0.155 \\
\hline Error & 30 & 0.02 & & & 28 & 0.02 & & & 30 & 0.04 & & \\
\hline
\end{tabular}


stream reach scale (Ferreira et al., 2015). Therefore, our results can be seen as conservative.

Fungal biomass and conidial production by aquatic hyphomycetes were also very low (maximum $97 \mu \mathrm{g}$ ergosterol/g AFDM and 2 conidia $\mathrm{mg}^{-1}$ AFDM d $\mathrm{d}^{-1}$ ), suggesting that aquatic hyphomycetes might not be the main microbial players at the initial stage of litter decomposition in the Indaiá stream or that microbial activity was highly limited by low dissolved nutrient availability in the study stream. Low fungal biomass and reproductive activity by aquatic hyphomycetes associated with submerged litter were found previously in the same (Gonçalves et al., 2006, 2007) and other tropical streams (Ferreira et al., 2012). A recent study showed a decrease in aquatic hyphomycete species richness from temperate regions to the tropics (Jabiol et al., 2013), which might partially explain the low representation of these fungi on decomposing litter in the Indaiá stream compared with temperate streams. The low fungal activity on decomposing litter may contribute to explain the low litter mass loss and the low magnitude of nutrient effects.

However, ATP concentrations on submerged litter were relatively high. This finding agrees with previous observations in the same stream (Gonçalves et al., 2006, 2007). High ATP concentrations suggest that other components of the microbial community (e.g., bacteria) may play a more crucial role in litter decomposition in tropical streams than aquatic hyphomycetes, which are often regarded as key microbial decomposers in temperate streams. This shift in relative importance from highly efficient decomposers (i.e., aquatic hyphomycetes) to relatively inefficient decomposers (Gulis \& Suberkropp, 2003b) could contribute to explain the low litter mass loss in these tropical streams.

Overall, the results support our initial hypothesis, suggesting that microbial colonisation and decomposition of low-quality leaf litter species in Cerrado streams is limited by low dissolved nutrient availability, as previously suggested by Gonçalves et al. (2007). Oligotrophic streams in the Cerrado are thus likely to be highly sensitive to anthropogenic activities that lead to nutrient enrichment (e.g., nutrient deposition, agriculture) (Gucker et al., 2009; Boechat et al., 2011).

\section{ACKNOWLEDGEMENTS}

This work was financed by Conselho Nacional de Desenvolvimento e Pesquisa (CNPq), Fundação de Amparo à Pesquisa do Estado de Minas Gerais (FAPEMIG), and Coordenação de Aperfeiçoamento de Pessoal de Nível Superior (CAPES). MC was awarded a CNPq productivity research grant (CNPq No. 302960/2011-2) and a researcher grant by FAPEMIG (FAPEMIG PPM00077/13) and AOM received a postdoctoral fellowship from CAPES. A GRICES/CAPES convenium (Bilateral agreement Portugal-Brazil. Research and Formation in Organic Matter Breakdown in Streams. Project no.: 4.1.3/ CAPES/CPLP) and financial support granted by the Portuguese Foundation for Science and Technology (FCT) to VF (postdoctoral fellowship SFRH/BPD/76482/2011, program POPH/FSE) are also gratefully acknowledged. We also thank the comments made by two anonymous reviewers on an early version of the manuscript, and Javier Pérez for revision of the text in Spanish.

\section{REFERENCES}

ABELHO, M. 2001. From litterfall to breakdown in streams: a review. The Scientific World Journal, 1: 656-80.

ABELHO, M. 2005. Extraction and quantification of ATP as a measure of microbial biomass. In: Methods to Study Litter Decomposition: A Practical Guide. M.A.S. GRAÇA, F. BÄRLOCHER \& M.O. GESSNER (eds): 223-229. Springer, Dordrecht.

ABELHO, M. \& M. A. S. GRAÇA. 2006. Effects of nutrient enrichment on decomposition and fungal colonization of sweet chestnut leaves in an Iberian stream (Central Portugal). Hydrobiologia, 560: 239-247.

ABELHO, M., M. MORRETI., J. FRANÇA., J. \& M. CALLISTO. 2010. Nutrient addition does not enhance leaf decomposition in a Southeastern Brazilian stream (Espinhaço Moutain range). Brazilian Journal of Biology, 70: 747-754. 
ALVAREZ-CLARE, S. \& M. C. MACK. 2011. Influence of precipitation on soil and foliar nutrients across nine Costa Rican forests. Biotropica, 43(4): 433-441.

APHA 2005. Standard Methods for the Examination of Water and Wastewater. $18^{\text {th }}$ ed. American Public Health Association. USA, Washington DC.

ARDÓN, M., L. A. STALLCUP \& C. M. PRINGLE. 2006. Does leaf quality mediate the stimulation of leaf breakdown by phosphorus in Neotropical streams? Freshwater Biology, 51(4): 618-633.

BALDY, V., V. GOBERT, F. GUEROLD, E. CHAUVET, D. LAMBRIGOT \& J. Y. CHARCOSSET. 2007. Leaf litter breakdown budgets in streams of various trophic status: effects of dissolved inorganic nutrients on microorganisms and invertebrates. Freshwater Biology, 52(7): 1322-1335.

BÄRLOCHER, F. 2005. Sporulation by aquatic hyphomycetes. In: Methods to Study Litter Decomposition: a Practical Guide. M. A. S. GRAÇA, F. BÄRLOCHER, M. O. GESSNER (eds): 185-187. Springer, Dordrecht.

BÄRLOCHER, F. \& M. CORKUM. 2003. Nutrient enrichment overwhelms diversity effects in leaf decomposition by stream fungi. Oikos, 101(2): 247-252.

BOECHAT, I. G., A. KRUGER., A. GIANI, C. C. FIGUEREDOS \& B. GUCKER. 2011. Agricultural land-use affects the nutritional qualityof streammicrobial communities. FEMSMicrobial Ecology, 77: 568-576.

BOYERO, L., R. G. PEARSON, D. DUDGEON, M. A. S. GRAÇA, M. O. GESSNER, R. J. ALBARIÑO, V. FERREIRA, C. M. YULE, A. J. BOUTON, M. ARUNACHALAM, M. CALLISTO, E. CHAUVET, A. RAMIREZ, J. CHARÁ, M. S. MORETTI, J. F. GONÇALVES, J. E. HELSON, A. M. CHARÁ-SERNA, A. C. ENCALADA, J. N. DAVIES, S. LAMOTHE, A. CORNEJO, A. O. LI, L. M. BURIA, V. D. VILLANUEVA, M. C. ZUNIGA \& C. M. PRINGLE. 2011. Global distribution of a key trophic guild contrasts with common latitudinal diversity patterns. Ecology, 92(9): 1839-1848.

BRUDER, A., M. H. SCHINDLER, M. S. MORETTI \& M. O. GESSNER. 2014. Litter decomposition in a temperate and a tropical stream: the effects of species mixing, litter quality and shredders. Freshwater Biology, 59(3): 438-449.

COLEY, P. D. \& J. A. BARONE. 1996. Herbivory and plant defenses in tropical forests. Annual Review and Ecology System, 27: 305-335.
FERREIRA, V., V. GULIS \& M. A. S. GRAÇA. 2006. Whole-stream nitrate addition affects litter decomposition and associated fungi but not invertebrates. Oecologia, 149: 718-729.

FERREIRA, V. \& E. CHAUVET. 2011. Synergistic effects of water temperature and dissolved nutrients on litter decomposition and associated fungi. Global Change Biology, 17(1): 551-564.

FERREIRA, V., A. C. ENCALADA \& M. A. S. GRAÇA. 2012. Effects of litter diversity on decomposition and biological colonization of submerged litter in temperate and tropical streams. Freshwater Science, 31(3): 945-962.

FERREIRA, V., B. CASTAGNEYROL, J. KORICHEVA, V. GULIS, E. CHAUVET \& M. A. S. GRAÇA. 2015. A meta-analysis of the effects of nutrient enrichment on litter decomposition in streams. Biological Reviews, 90: 669-688.

GESSNER, M. O. 2005. Ergosterol as a measure of fungal biomass. In: Methods to Study Litter Decomposition: a Practical Guide. M. A. S. GRAÇA, F. BÄRLOCHER, M. O. GESSNER (eds): 189195. Springer, Dordrecht.

GESSNER, M. O. \& E. CHAUVET. 1994. Importance of stream microfungi in controlling breakdown rates of leaf litter. Ecology, 75: 1807-1817.

GESSNER, M. O. \& E. CHAUVET. 2002. A case for using litter breakdown to assess functional stream integrity. Ecological Applications, 12(2): 498-510.

GIULIETTI, A. M., J. R. PIRANI \& R. M. HARLEY. 1997. Espinhaço range region. Eastern Brazil. In: Centres of Plant Diversity. A Guide and Strategy for their Conservation. S. D. DAVIS, V. H. HEYWOOD, O. HERRERAMACBRYDE, J. VILLALOBOS \& A. C. HAMILTON (eds): 397-404. The Americas, WWF/IUCN, UK, Cambridge.

GONÇALVES, J. F., M. A. S. GRAÇA \& M. CALLISTO. 2006. Leaf-litter breakdown in 3 streams in temperate, Mediterranean, and tropical Cerrado climates. Journal North American Benthological Society, 25(2): 344-355.

GONÇALVES, J. F., M. A. S. GRAÇA \& M. CALLISTO. 2007. Litter decomposition in a Cerrado savannah stream is retarded by leaf toughness, low dissolved nutrients and a low density of shredders. Freshwater Biology, 52(8): 1440-1451.

GONÇALVES, J. F., R. S. REZENDE, N. MARTINS \& R. S. GREGÓRIO. 2012. Leaf breakdown in a Atlantic Rain Forest Stream. Austral Ecology, 37(7): 807-815. 
GRAÇA, M. A. S. 2001. The role of invertebrates on leaf litter decomposition in streams - A review. International Review of Hydrobiology, 86(4-5): 383393.

GUCKER, B. R., I. G. BOECHAT \& A. GIANI. 2009. Impacts of agricultural land use on ecosystem structure and whole-stream metabolism of tropical Cerrado streams. Freshwater Biology, 54(10): 2069-2085.

GULIS, V. \& K. SUBERKROPP. 2003a. Leaf litter decomposition and microbial activity in nutrientenriched and unaltered reaches of a headwater stream. Freshwater Biology, 48: 123-134.

GULIS, V. \& K. SUBERKROPP. 2003b. Interactions between stream fungi and bacteria associated with decomposing leaf litter at different levels of nutrient availability. Aquatic Microbiol Ecology, 30(2): 149-157.

GULIS, V., V. FERREIRA \& M. A. S. GRAÇA. 2006. Stimulation of leaf litter decomposition and associated fungi and invertebrates by moderate eutrophication: implications for stream assessment. Freshwater Biology, 51(9): 1655-1669.

HIEBER, M. \& M. O. GESSNER. 2002. Contribution of stream detrivores, fungi, and bacteria to leaf breakdown based on biomass estimates. Ecology, 83(4): 1026-1038.

JABIOL, J., A. BRUNER, M. O. GESSNER, M. MAKKONEN, B. G. McKIE, E. T. H. M. PEETERS, V. C. A. VOS \& E. CHAUVET. 2013. Diversity patterns of leaf-associated aquatic hyphomycetes along a broad latitudinal gradient. Fungal Ecology, 6(5): 439-448.

LECERF, A. \& E. CHAUVET. 2008. Intraspecific variability in leaf traits strongly affects alder leaf decomposition in a stream. Basic and Applied Ecology, 9(5): 598-605.

MARKEWITZ, D., J. C. F. RESENDE., L. P. M. BUSTAMANTE., C. A. KLINK., R. O. FIGUEIREDO \& E. A. DAVIDSON. 2006. Dissolved rainfall inputs and streamwater outputs in an undisturbed watershed on highly weathered soil in the Brazilian cerrado. Hydrological Processes, 20: 2615-2639.

MCKIE, B. G., M. SCHINDLER, M. O. GESSNER \& B. MALMQVIST. 2009. Placing biodiversity and ecosystem functioning in context: environmental perturbations and the effects of species richness in a stream field experiment. Oecologia, 160(4): 757-770.
MORETTI, M. S., J. F. GONÇALVES \& M. CALLISTO. 2007a. Leaf breakdown in two tropical streams: differences between single and mixed species packs. Limnologica, 37: 250-258.

MORETTI, M. S., J. F. GONÇALVES, R. LIGEIRO \& M. CALLISTO. 2007b. Invertebrates colonization on native tree leaves in a neotropical stream (Brazil). International Review of Hydrobiology, 92(2): 199-210.

MYERS, N., R. A. MITTERMEIER, C. G. MITTERMEIER, G. A. B. FONSECA \& J. KENT. 2000. Biodiversity hotspots for conservation priorities. Nature, 403(6772): 853-858.

ORDOÑEZ, J. C., P. M. VANBODEGOM, J.-P. M. WITTE, I. J. WRIGHT, P. B. REICH \& R. AERTS. 2009. A global study of relationships between leaf traits, climate and soil measures of nutrient fertility. Global Ecology and Biogeography, 18(2): 137-149.

PASCOAL, C. \& F. CÁSSIO. 2004. Contribution of fungi and bacteria to leaf litter decomposition in a polluted river. Applied and Environmental Microbiology, 70(9): 5266-5273.

ROBINSON, C. T. \& M. O. GESSNER. 2000. Nutrient addition accelerates leaf breakdown in an alpine springbrook. Oecologia, 122(2): 258-263.

ROCKSTRÖM, J., W. STEFFEN, K. NOONE, A. PERSSON, F. CHAPIN, E. F. LAMBIN, T. M. LENTON, M. SCHEFFER, C. FOLKE, H. J. SCHELLNHUBER, B. NYKVIST, C. A. de WIT, T. HUGHES, S. VANDER LEEUW, H. RODHE, S. SORLIN, P. K. SNYDER, R. COSTANZA, U. SVEDIN, M. FALKENMARK, L. KARLBERG, R. W. CORELL, V. J. FABRY, J. HANSEN, B. WALKER, D. LIVERMAN, K. RICHARDSON, P. CRUTZEN \& J. A. FOLEY. 2009. A safe operating space for humanity. Nature, 461(7263): 472-475.

ROSEMOND, A. D., C. M. PRINGLE, A. RAMIREZ, M. J. PAUL \& J. L. MEYER. 2002. Landscape variation in phosphorus concentration and effects on detritus-based tropical streams. Limnology and Oceanography, 47(1): 278-289.

SILVA, L. V. \& H. L. VASCONCELOS. 2011. Plant palatability to leaf-cutter ants (Atta laevigata) and litter decomposability in a Neotropical woodland savanna. Austral Ecology, 36(5): 504-510.

STALLCUP, L. A., M. ARDÓN. \& C. M. PRINGLE. 2006. Does nitrogen become limiting under high$\mathrm{P}$ conditions in detritus-based tropical streams? Freshwater Biology, 51(8): 1515-1526. 
VÖRÖSMARTY,C. J., P. B. McINTYRE, M. O. GESSNER, D. DUDGEON, A. PRUSEVICH, P. GREEN, S. GLIDDEN, S. E. BUNN, C. A. SULLIVAN, C. R. LIERMANN \& P. M. DAVIES. 2010. Global threats to human water security and river biodiversity. Nature, 467(7315): 555-561.

WEBSTER, J. R. \& E. F. BENFIELD. 1986. Vascular plant breakdown in freshwater ecosystems. Annual Review of Ecology and Systematics, 17: 567-594. YOUNG, R. G., C. D. MATTHAEI \& C. R. TOWNSEND. 2008. Organic matter breakdown and ecosystem metabolism: functional indicators for assessing river ecosystem health. Journal of the North American Benthological Society, 27(3): 605-625. 